\title{
Daz ve Dazlak Sözcükleri Hakkında ${ }^{1}$
}

\author{
Anıl ÇELİK \\ Dr. Öğr. Üyesi, Bartın Üniversitesi \\ Edebiyat Fakültesi, Türk Dili ve Edebiyatı Bölümü \\ acelik@bartin.edu.tr \\ Orcid ID: https://orcid.org/0000-0001-6035-5303
}

\begin{abstract}
Öz
Türkçede anlam genişletici ya da anlam değiştirici kimi eklerle muhtelif şekillerde teşekkül etmiş olmalarına karşın taban anlamlarına geri dönen ve "döngülü sözcükler" olarak adlandırılabilecek kimi sözcükler vardır. Bu türden sözcüklerin geçirdikleri süreç "anlamsal döngü” olarak adlandırılabilir. "daz $\Leftrightarrow$ dazlak" eklemlenmesinde de anlamsal döngü süreci başlamıştır. "Dazlak" sözcüğü tabanı olan "daz" sözcüğüyle aynı anlamda kullanılabilmektedir ve "daz" sözcügünün dildeki kullanımını sınırlasa da onu kullanımdan henüz tamamıyla düşürmemiştir. Dolayısıyla döngü sürecinin devam ettiği söylenebilir. $\mathrm{Bu}$ çalışmada söz konusu anlamsal döngü sürecinin işleyiş̧ini ve sebeplerini anlayabilmek adına "daz" ve "dazlak" sözcüklerinin etimolojilerine değinilmiş, bu sözcüklerin Türkçenin tarihî kaynaklarındaki durumlarına göz atılmış, ölçünlü Türkiye Türkçesi, Türkiye Türkçesi ağızları ve çağdaş Türk lehçelerindeki kullanımları örneklendirilmiş, elde edilen bilgilerden yola çıkılarak anlamsal döngüler ile ilgili birtakım çıkarımlarda bulunulmuştur. Araştırmanın, ilgili sözcüklere dair tartışmaları ve çözümlemeleri ortaya koyması, "+1Ak” ekinin "türetme" işlevinden ayrılan "genişletme" işlevini dikkate sunması ve genişletme eklerinin "anlamsal döngülerin" ortaya çıkışındaki rolünü bu yolla örneklendirmesi açısından alana katkı vermesi hedeflenmektedir.
\end{abstract}

Anahtar Kelimeler: Daz, Dazlak, Anlamsal Döngü, +lAk Eki, Ekler.

\footnotetext{
${ }^{1}$ Makale Geliş/Kabul Tarihi: 19.06.2020 / 27.01.2021

Künye Bilgisi: Çelik, A. (2021). Daz ve dazlak sözcükleri hakkında. Kahramanmaraş Sütçü Imam Üniversitesi Sosyal Bilimler Dergisi, 18(1), 327-350. DOI: 10.33437/ksusbd. 755040
} 


\title{
On The Words of Daz And Dazlak
}

\begin{abstract}
There are some words in Turkish that can be termed as "döngülü sözcükler" that return meaning to their bases even though they have been formed in various ways with some expansions or changes of meaning. The process by which such words go through can be called a "anlamsal döngü". In the formation of "daz $\Leftrightarrow$ dazlak", the process of "anlamsal döngü" has started. The word "Dazlak" can be used in the same sense as the word "daz", which is its base, but although this word limits the use of the word "daz", it has not yet completely dropped it from use in Turkish. This indicates that the "döngü" process is ongoing. In this study, in order to understand the functioning and causes of the "anlamsal döngü" process in question, the etymologies of the words "daz" and "dazlak" is discussed, the word "daz" and the status of their derivatives in Turkish historical sources is observed, the usage of these structures in standard Turkish, subdialects of Turkish and modern Turkic languages are shown and some inferences are made about "anlamsal döngü" process based on this information. The aim of the research is to provide discussions and analyses on the words mentioned, to present the "extension" function that is separated from the "derivation" function of the "+lAk" suffix and to contribute to the field in order to exemplify the role of "extensional” suffixes in the emergence of "anlamsal döngü” process in this way.
\end{abstract}

Keywords: Daz, Dazlak, Semantics, + lAk Suffix, Suffixes.

\section{GÍRIŞ}

"Daz” ve "dazlak” sözcüklerinin her ikisi de günümüz Türkiye Türkçesinde "başında saçı olmayan (kimse, baş)" (Türk Dil Kurumu, n.d.) anlamlarında kullanılmaktadır. Tıpkı bu örnekler arasındaki ilişkide görüldüğü gibi Türkçede bazı sözcükler anlam genişletici yahut anlam değiştirici birtakım eklerle çeşitli biçimlerde eklemlenmiş olmalarına karşın taban anlamlarına geri dönerler. $\mathrm{Bu}$ türden yapılar "döngülü sözcükler", gerçekleşen süreç ise "anlamsal döngüler" olarak nitelenebilir. "Ortaya çıkan sözcük, taban anlamına geri döndükten sonra tabanının dilde kullanımdan düşmesine sebebiyet veriyorsa bu durum döngünün tamamlandığını gösterir" (Çelik, 2020: 18). Yukarıdaki bilgiler göz önüne alındığında "taz / daz $\Leftrightarrow$ dazlak" eklemlenmesinde anlamsal döngünün tam olarak nihayete ermediği görülmektedir. Zira "dazlak" sözcüğü "daz” tabanının dildeki kullanım oranını sınırlandırsa da onu tamamıyla kullanımdan düşürmemiştir. Bu durum, döngü sürecinin devam ettiğine işaret eder. 
Aşağıda, bahsi geçen anlamsal döngü sürecinin nedenlerini ve işleyiş tarzını kavrayabilmek amacıyla "daz" ve "dazlak" sözcüklerinin kökenleri hakkında bilgi verilmiş, bu sözcüklerin Türkçenin tarihî kaynaklarındaki durumlarına göz atılmış, ölçünlü Türkiye Türkçesi, Türkiye Türkçesi ağızları ve çağdaş Türk lehçelerindeki konumları belirlenmeye çalışılmış, bu doğrultuda anlamsal döngüler ile "+lAk" eki hakkında birtakım tespitlerde bulunulmuştur. Çalışmanın, bahsi geçen sözcüklerle ilgili dilsel tartışmaları ve tahlilleri ortaya koyması, "+1Ak" ekinin "türetme" işlevinden ayrılan "genişletme" işlevini gündeme getirmesi, genişletme eklerinin "anlamsal döngülerin" ortaya çıkışındaki rolünü bu yolla örneklendirmesi ve böylelikle alana katkı sunması amaçlanmaktadır.

\section{DAZ VE DAZLAK SÖZCÜKLERININ ETIMOLOJILERI HAKKINDA}

Clauson'un (1972: 570) "An Etymological Dictionary of Pre-Thirteenth Century Turkish" (EDPT) isimli sözlügünde "taz" madde başı ile ilgili çeşitli açıklamalar ve çıkarımlar mevcuttur. Bu eserde "kel" anlamına gelen taz sözcüğünün genellikle "taz/taS" görünümlerinde ve birtakım genişletilmiş anlamlarıyla beraber ilgili modern dil gruplarında hayatta kalmış olduğundan bahsedilir. "An Etymological Dictionary of Altaic Languages"'te "daz" sözcüğünün kökeni Ana Altaycadaki varsayımsal "t éro" yapısına dayandırılır:

t éro bald: Mong. *tar-; Turk. *daŕ ( -ā-); Kor. *tăi- / tắrk.PMong. *tar- 1 bald 2 scab (on head) (1 лысый 2 парша): MMong. tarasun 'bald, naked' (HY 48), țrya 1 (IM); WMong. tar 1, tarayai 2; Kh. tar 'having sparse hair' (БАMPC); Kalm. tar 1; Mongr. $\operatorname{tarG} \bar{a}$ 'chauve, rasé (tête), nu (terre)'. $\diamond$ KW 380. Mong. > Yak. tarayaj, Dolg. tarakaj 'bald' (Stachowski 217). PTurk. *daŕ ( ā-) bald (лысый): OTurk. taz (OUygh.); Karakh. taz (MK); Tur. daz; Az. daz; Sal. taz (ССЯ); MTurk. taz (Sangl.); Uzb. toz; Uygh. taz; Krm. taz; Tat. taz; Bashk. ta反; Kirgh. taz; Kaz. taz; KKalp. taz Nogh. taz; Khak. tas; Shr. tas; Oyr. tas; Tv. tas; Tof. tas.

$\checkmark$ VEWT 467, EDT 570, ЭСТЯ 3, 124. Turk. > Hung. tar 'bald', see MNyTESz 3,847 . PKor. *tăi- / tắrk 1 a bald head 2 cracks (on hands and feet, from cold) (1 лысая голова 2 трещины (на руках и ногах, от холода)): MKor. tắrk 2; Mod. tä-məri 1. $\diamond$ Liu 185, KED 426. \| EAS 111, KW 380, SKE 250, Poppe 13. Despite Щербак 1997, 154 we cannot assume borrowing in Mong. from Turkic. Turkic has a secondary voiced d- (one of the cases of voicing in front of -ŕ-); but a contamination of two roots is also not excluded: cf. also Mong. dar-gar, dars-gar 
(L 233: darsa-yar) ‘rough, warped (of skin)’. Cf. also notes to *t ếra ( -o) ‘eagle, vulture’ (Starostin vd., 2003: 1423).

Hasan Eren (1986), sözlüğünde konuyla ilgili olarak "saçı dökülmüş (baş), dazlak" şeklinde bir tanımlama verir ve ağızlardaki "dızlak" yapısının da aynı anlama geldiğini söyler (Eren 1986: 106),. “Daz” sözcügünün bilimsel yayımlarda sıklıkla Moğolca "tar" ve "taraqai" ile birleştirildiğinden söz eder. Macarca "kel" anlamındaki "tar" sözcüğünün Çuvaş özellikleri taşıyan eski bir Türk dilinden alındığını belirtir. Eyüboğlu (1991) "daz: çıplak, saçsız, saçı dökülmüş baş” şeklinde bir tanımlama verdikten sonra DLT'deki açıklamalar ve kullanımları sıralar (Eyüboğlu 1991: 171-172). Ardından Türkiye Türkçesi ağızlarındanki ilgili bazı kullanımları örneklendirir. Tietze (2002) "daz" madde başı altında "saçsız baş, kel" tanımlamasını verir ve sözcüğün kullanıldığı tarihî kaynaklardan örnekler gösterir (Tietze 2002: 570). Gülensoy (2007) “daz" sözcüğünü "kel, çorak" tanımlamasıyla açıklar (Gülensoy 2007: 270). "Eski Çuvaşça *tar> Macarca tar "kel, saçsız"” gelişimini gösterir ve başka birtakım kaynaklarda da belirtilen bu bilgiyi dikkatlere sunar. "Dazkırı" Türkçe yer adını "daz" sözcüğüyle kurulmuş bir yapı olması dolayısıyla örnek olarak gösterir. Kazakça "tarbaka" "kurbağa" (tar+bāka) ve Moğolca "tarbalci" "akbaba"<"tar" "kel”+"balci" "baş (=kel baş) kullanımlarının "tar" sözcüğüyle kurulmuş olduğuna dikkat çeker. Türkçenin diğer etimoloji sözlüklerinde de "taz/daz" sözcüğüyle ilgili olarak çoğunlukla benzer bilgiler tekrarlanır.

Eren (1986) "dazlak" madde başını "daz" madde başıyla birlikte ele alır ve "dazlak” için müstakil bir bilgi vermez (Eren 1986: 106). Eyüboğlu (1991) "dazlak" maddesini "saçsız baş, çıplak baş" şeklinde tanımlar ve "daz+lak" şeklinde bir tahlil yapar (Eyüboğlu 1991: 172). Nişanyan (n.d.) tarihî ve çağdaş kaynaklardaki ilgili kullanımlardan örnekler verdikten sonra " $(<$ ET tazlakelleşmek) $<$ ET taz kel +1Ak" şeklinde bir eklemlenme önerisinde bulunur. Tietze (2002) "dazlak/dızlak" başlığı altında "başında veya tepesinde saçı olmayan" tanımını verir. Onun önerdiği eklemlenme şu şekilde gösterilebilir: “daz 'kel, saçsız'; daz+1A- 'saçları dökülmek, kelleşmek' [+1A- ekinin isimlerden "bu gibi hale gelmek" manasında fiiller yapma niteliği vardır); daz+lA-k "kel, saçsız' (Tietze 2002: 570). Benzer bir görüşte olan Gülensoy (2007) da "dazlak” maddesini "saçsız, kel" şeklinde tanımladıktan sonra $(<$ ET taz+1A-k "sıfat yapan ek’) eklemlenmesini verir (Gülensoy 2007: 270). Türkçenin etimolojik sözlükleri "dazlak" sözcügünün nasıl tanımlanacağı konusunda büyük oranda hemfikirdir. Bu sözcüğün eklemlenmesi ise çoğunlukla "taz/daz+lA-k" ya da "taz/daz+lAk" şeklinde gösterilmiştir. 


\section{“TAZ/DAZ” SÖZCÜĞÜ VE TÜREVLERINIIN TÜRKÇENINN TARİHÎ KAYNAKLARINDAKİ DURUMU}

\section{Taz/Daz}

EDPT'de sekizinci yüzyıl Uygur Türkçesine ait "kendilerinden beş bakır paralık at vergisi toplanan kişilerin yer aldığı bir liste"de bulunan şahıs isimlerinden "Çoba Yıkmış" ve "Yıkmış Taz" adlandırmalarının muhtemelen "Kel Yıkmış" anlamına geldiği bununla ilgili farklı okumalar da yapılabileceği uyarısıyla birlikte verilir (Clauson, 1972: 570). Eğer bu okumalar doğruysa Eski Türkçede "taz" sözcüğüyle bir şahıs isminin bünyesinde "saçsız, kel" anlamıyla karşıllaşıldı

On birinci yüzyılda DLT'de "taz" sözcüğü ve bu sözcükten türetilmiş başka birtakım sözcükler dikkati çeker. Bu sözlükte "taz" sözcügünün kullanımları çeşitli cümlelerle örneklendirilmiştir.

Bu kullanımlardan biri "Taz keligi börkçike. [Kelin (dazlağın) gelişi börkçü dükkanınadır]" (Ercilasun ve Akkoyunlu, 2018: 9) atasözü içinde kendine yer bulur. DLT'de bu atasözüyle ilgili şu şekilde bir açıklama mevcuttur: "Başka çaresi yok, kelini örtmek için oradan bir şey satın alması lazım. Yapması gereken şeyden kaçan için söylenir" (Ercilasun ve Akkoyunlu, 2018: 245). Bu atasözünü, Abdülahad Nûrî "Kelin gelişi (insan yanına çıkması) başı örtülü olaraktır" (Atlı, 2019: 2266) şeklinde ifade eder.

Aydemir (2013) Kaşgarlı Mahmud'un çağdaşı Yusuf Has Hacib'in "Tişide uwut kitti örtmez yüzin" ifadesini hatırlatarak DLT'deki "Taz keligi börkçige" atasözünün bu görüşü tasdik eder göründügünü fakat kişi kıyafetlerinde tesettürün Türklerin hayatına İslâmiyetle birlikte dâhil olduğunu ve dolayısıyla Yusuf Has Hacib'in söylediklerinin İslamiyet'in etkisinin bir nişanesi olarak değerlendirilmesi gerektiğini belirtir. Bundan yola çıkarak bir kişinin başının açık olması ya da saçlarının az olmasının da benzer şekilde sövmeyi ve onur kırmayı gerektirmediğini söyler. Aydemir (2013) "Kellik"in, Türk dünya görüşünde kınanılacak bir vaziyet olmadığını (Aydemir, 2013: 226), Ergun (2005), Ögel (2002) ve Beydilli'nin de (2005) belirttiği gibi tanrı kutunu sembolize ettiğini, olgunluk ve bilgelik göstergesi olduğunu dile getirir (Ergun, 2005: 79; Ögel, 2002: 77-87 ve Beydilli, 2005: 306-308). Ancak Türk atasözleri arasında kelliğin -birçok zaman mecâzî anlamda- bir aşağılama, bir kınama aracı olarak kullanılması, kellikten utanılması son derece yaygındır ve atasözlerinin de toplumsal bilinçaltının en önemli yansımalarından olduğu unutulmamalıdır. Toplum bir kavram üzerinden çok farklı bakış açılarını ifade edebilmektedir. 
Örneğin Çelik (2016), “deliler”le ilgili atasözleri üzerine yaptığı çalışmada Türklerin delilere hem olumlu hem de olumsuz birçok sıfat yüklediğini ortaya koymuştur. Tipk1 “delilik"te olduğu gibi Türk toplumsal bilinçaltı "kellik"e de olumlu vasıflar yüklemiştir ${ }^{2}$ ancak "kellik" hakkındaki olumsuz ön yargıları da çok fazladır. Tergip'in (2014) sıraladığı "Türk Atasözü ve Deyimlerinde Kötüleme İfadeleri" arasında "kellik"in de olduğu görülür. Türkiye Türkçesindeki ilgili atasözlerine göz atıldığında bu "kötüleme ve aşağılama" rahatlıkla görülecektir:

dazlayan daza düşer, kel başlı kıza düşer [evleneceği kişiyi seçmekte çok titizlik gösteren kimse, çoğu kez istemediği, beğenmediği bir kişiye düşer.]; kaz kazla, daz dazla, kel tavuk kel (topal) horozla [herkes kendi durumuna uygun gelen kişilerle anlaşıp arkadaşlık ederler.]; (birinin) keli görünmek [tkz. kusuru ortaya çıkmak.]; hem kel hem fodul [yetenekli olmadı̆̆ hâlde üstünlük taslayanlar için kullanılan bir söz]; iyilik et kele, övünsün ele [bir kişinin beğenilmeyen yönlerini düzelt, onu herkesin övüneceği duruma getir.]; kel başa şimşir tarak [birçok gereksinimi varken gereksiz özenti ve gösterişle uğraşanlar için kullanılan bir söz.]; kel ilaç bilse kendi başına sürer [kendi işini halledemeyen kişiden aynı durum için yardım alınamaz.]; kel ölür, sırma saçlı olur, kör ölür badem gözlü olur [bir kimse veya bir şey yok olduğunda değer kazanır.]; keli körü toplamak [işe yaramaz kimseleri toplamak.]; kelin ayıbını takke örter [birçok kimsenin kusurunu zenginlik, makam vb. durumlar örter.]; kelin medarı olsa kendi başına olur[ kendi işini halledemeyen kişiden aynı durum için yardım alınamaz.]; takke düştü, kel göründü [bir ayıbı örten şey ortadan kalktığı zaman gerçek ortaya çıkar.]; tut kelin perçeminden [tkz. çözümü güçlük gösteren bir durum karşısında söylenen bir söz.] (Türk Dil Kurumu, n.d.).

O halde DLT'de yer alan "taz: kel çıplak" ve Oğuzların kullandığı ve Farsça kökenli bir sözcük olduğu düşünülen "tas: kötü olan her şey" sözcüklerinin anlamları, Aydemir'in $(2013,2017)$ belirttiği birtakım kullanımlarda gerçekten

2 Eski Türklerde "kellik"; güç, zekâ, saflık, bilgelik, olgunluk ve kutsiyetle de ilişkilendirilmiştir. Orta Asya tarihinde kel-dazlak atalar vardır (Ergun, 2005: 79; Bolat, 2017: 210) Türk mitolojisinde kelliğe atfedilen olumlu özelliklere sahip kahramanlara dair farklı kaynaklarda pek çok farklı ize daha rastlanır (Örn. Tastarakay, Tazşa, Tazhanım, Kaldaz Hanım, Keley vb.). Ancak bunun yanında, misalen Keloğlan, Türk kültüründe kelliğe atfedilen olumlu özelliklerin pek çoğunu bünyesinde taşıyan bir karakter olmakla birlikte bazı masalların nihayetinde ödül olarak saçları sırmalaştırılır ve dazlıktan kurtulup adeta kıvandırılır. Yahut bizler, başardıklarıyla noksan niteliklerini örten Keloğlan'ı bundan böyle saçlı şekilde tahayyül etmeyi tercih ederiz (Şimşek, 2017: 46). 
iç içe geçti ise bunun sebebi şekilsel benzerliğin yanında "dazlık" yani kelliğin Türk kültüründe "kötülenmeyle" doğrudan ilişkilendirilebilmesi olmalıdır.

Bir diğer örnekle de "Taz başı ajmuklandı. [Kelin başı bozuldu ve kelliği artt1]" (Ercilasun ve Akkoyunlu, 2018: 137) cümlesinde karşılaşılır. DLT'de "ajmuk" maddesinde "beyaz şap" anlamı verildikten sonra "ajmuk taz" ifadesi geçer ve bunun "sanki kelin kafasına şap sürülmüştür" anlamına geldiği ifade edilir (Ercilasun ve Akkoyunlu, 2018: 48). Clauson (1972) "ajmuklan-” fiilinin bir "hapax legomenon" olduğunu belirtir ve "kel adamın baş" anlamıyla birlikte ifadenin "sağlıksızlıkla" ilişkilendirilebileceğini söyler (Clauson, 1972: 27). Aydemir (2012) bu ifadeyi "saçkıran" hastalığıyla alakalı görür (Aydemir 2012: 341). Ögel (1991) ise söz konusu yapıyla ilgili saçı olmayan ve kafası çok parlak olanlara "ajmuk taz" dendiğini söyler ve "başın şapla sıvanması" bağını kurar (Ögel, 1991: 281-283).

"Taz" sözcüğünün "saçsız, kel” anlamlarının yanı sıra genişletilmiş biçimleriyle başka kullanımlarının da olduğu DLT'de belirtilmiştir. Bu kullanımlar "taz kōy", "taz yir" ve "taz at" şeklindedir.

taz kōy: boynuzsuz koyun (Ercilasun ve Akkoyunlu, 2018: 408).

Birçok kaynakta "taz kōy" yapısı için DLT'de ifade edilen "boynuzsuz koyun" tanımlaması tekrarlanır. Bunlardan başka, örneğin Efe (2018) "Eski Türkçe Döneminde Hayvan Türlerinin Adlandırılması" isimli çalışmasında DLT'deki "taz at: alacalı at" tanımını da göz önünde bulundurarak "taz kōy" ifadesini "alacalı, kel, boynuzsuz koyun" şeklinde tanımlamış ve bu isimlendirmeyi "Renklerine Göre Verilen Hayvan Adları" başlığı altında değerlendirmiştir (Efe, 2018: 334). Aydemir (2017) DLT'deki ‘taz' sözcügünün 'daz, kel' anlamı harîcinde Oğuzlarca kullanılan "tas" sözcügüyle bağlantılı 'kötü, fena, hayâsız, fahişe, yosma' anlamında örtmece bir sözcük olarak da kullanıldığını savunur. Dolayısıyla "taz kōy" ifadesi için "kötü koyun, zayıf, c1lız koyun" şeklinde bir tanımlama önerir (Aydemir, 2017: 51). Ancak "çıplak, kel" karşıllı̆ındaki "taz" sözcüğü, anlam itibarıyla "boynuzsuz" ifadesini karşılayacak niteliktedir ve ifadenin anlamının başka bir şekilde algılanması için net bir sebep yoktur. Ayrıca, Türkler "boynuzsuz" ve "kel" ifadeleri için ortak başka sözcükler de kullanmışlardır. "Tokluk"3 , ve "sokar” sözcükleri buna örnektir (Ögel, 1991: 281-283).

3 Tokluk: Boynuzsuzluk. İnsan başının saçsız hayvanın boynuzsuz olması (Ercilasun ve Akkoyunlu, 2018: 205). 
taz yir: çorak (bitkisi) az olan yer. (Ercilasun ve Akkoyunlu, 2018: 408).

Birçok kaynakta "taz yir" yapısı için DLT'de ifade edilen "çorak, (bitkisi) az olan yer" tanımlaması tekrarlanır. Clauson (1972) bu ifadeyi "çorak ve tuzlu toprak" şeklinde açıklar (Clauson, 1972: 570). Aydemir (2017) "taz" sözcüğünü "tas" sözcüğü ile ilişkilendirir ve "kötü" anlamına gelen bir ifade olduğunu vurgulayarak "verimsiz toprak, çorak yer" şeklinde bir tanımlama verir (Aydemir, 2017: 51). Bununla birlikte, aynı çalışmasında Aydemir (2017) "Toprağın verimliliği ile insanların saçlarının gürlüğü arasında bir ilginin kurulduğu DLT'den anlaşılmaktadır." şeklinde bir yorum yapar (Aydemir, 2017: 48). "Taz yir" ifadesindeki kullanımın "kel" anlamındaki "taz" ile ilişkisi aşikardır. "Saç çıkmayan" ve "ot bitmeyen" ifadeleri arasındaki anlam ilişkisi çok net bir şekilde görülebilmektedir. Dolayısıyla anlam ilişkisini başka yerde değil burada aramak gerekir. Keza Türkçenin daha ileriki dönemlerinde, hatta günümüzde dahi “daz”, “dazlak” ve "kel” ifadeleri bu yönden benzetmelerle yer isimlerinde kullanılmıştır. "Daz” sözcüğünün Türk Dil Kurumu (TDK) Güncel Türkçe Sözlük’te (Türk Dil Kurumu, n.d.) birincil anlamı "dazlak" ve ikincil anlamı da "çılak (toprak)" şeklindedir. Derleme Sözlüğü'ndeki anlamlarından biri "Otsuz, çıplak arazi, tepe" şeklinde kayıtlıdır. Bu yönelim yer adlarında da kendini gösterir. Bugün Türkiye'de çeşitli illerdeki yer adlarından olan "Daztepe", "Dazlaktepe" ile "Keltepe" aynı anlamı ifade edecek şekilde kurulmuş adlardır. TDK Güncel Türkçe Sözlük’te "kel” sözcügünün mecaz anlamlarından biri "Çıplak (doğa)" şeklindedir (Türk Dil Kurumu, n.d.).

taz at: alacalı at. "taz at tawarçı bolmas" [alacalı at yük taşıyamaz çünkü kötü toynaklıdır] (Ercilasun ve Akkoyunlu, 2018: 408).

Çoğu kaynakta "taz at" yapısı için DLT'de ifade edilen "alacalı at" tanımlaması tekrarlanır. Clauson (1972) "taz” sözcüğünün 11. yüzyı1 Hakaniye Türkçesindeki kullanımlarını örneklendirirken "taz at" kullanımının alışılagelmiş bir yapı olmadığını ve DLT'de geçen "taz at tawarçı bolmas" atasözündeki yapının hem "nalsız at" hem de "ayağı ağrımış at" anlamlarını sezdirdiğini belirtir (Clauson, 1972: 570). Sağol (1994) "taz at" ifadesinin "ayağında bir sakatlı̆̆1 olan at, yumuşak, düz ayaklı at" anlamına gelebiliyor olacağını söyler ve bu ifadenin anlamını "alaca at" olarak görme eğiliminde olmadığını ifade eder (Sağol, 1994: 140). Söz konusu ifadenin ne anlama geldiğini kavrayabilmek için Clauson'un da işaret ettiği "ayağı nalsız at, ayağı ağrımış at" ifadesine odaklanmak fayda sağlayabilir gibi gözükmektedir. "Daz"- "çıplak" anlam ilişkisi açısından bakıldığında "ayağı çıplak at" yani "nalsız at" "daz" sözcüğüyle ifade ediliyor olabilir. [Çağdaş Türk Lehçelerinden Hakas Türkçesindeki "tazay- 
" "ayakları açık vaziyette ayakta durmak" Arıkoğlu (2005) da "çıplak ayaklılık" bağlamında dikkati çeker.] Zira saha şartlarında çalıştırılan atlara nal takılmazsa ayakları incinebilir, acıyabilir ve ağrıyabilir (Arıkoğlu, 2005: 487).

Öte yandan Aydemir (2017) ise "taz" sözcüğünü "tas" sözcüğü ile ilişkilendirir ve bunun "kötü" anlamı taşıyan bir ifade olduğunu vurgulayarak "kötü at, tırnakları yıpranmış at" şeklinde bir tanımlama verir (Aydemir, 2017: 51). DLT'deki "tas" "kötü olan her şey" sözcügü için verilen "Bu at tas tegüll" Ercilasun ve Akkoyunlu, (2018) örneğine bakilacak olursa buradaki "tas" "kötü" sözcüğü doğrudan "at" ismiyle ilgili olarak kullanılmıştır ve bu kullanımın da böyle bir anlamsal iç içe geçmenin söz konusu olabileceğini düşündürdüğü belirtilmiştir (Ercilasun ve Akkoyunlu, 2018: 143).

“Taz/Daz" sözcüğü yukarıdaki kullanımlar haricinde Türkçenin farklı tarihî dönemlerinde kullanılagelmiştir. Janos Eckmann'ın bir 14. yüzyıl Harezm Türkçesi eseri olan Nehcü'l-Ferâdîs ile ilgili çalışmasında eserde "taz" sözcügünün geçtiği gösterilen cümlede bu sözcügün yanına bir yıldız konulmuş ve “*Yazmada lar saçlig, çekimleme yanlışı?" şeklinde bir not düşülmüştür: "Çaqır gözlüg bolgay, taz saçlı̀g bolg̀ay..." [Çakır gözlü olacak, daz saçlı olacak...] (Eckmann, 2014: 277). Yine 14. yüzyıla ait Kısas-1 Enbiyâ'da (Türk Dil Kurumu, 1995: 1031) da "taz" sözcüğünün kullanımına rastlanır: "Pes Tanrı Taâlâ anın boyun altmış arşına erdirdi ve andan ileri başı buluda erer idi. Depesi taz olmuş idi”. Sözcük, 15. yüzyılda yazılmış Âşıkpaşazâde Tarihi'nde şu şekilde geçer: "Kimi dün gün dürişür mankır ister/ Yüler saçın sakal başın taz eyler" [Kimi gece gündüz çalışır mankır (para) ister / Saçını sakalını yolar, başını daz eyler.] (Giese, 1929: 62; Tietze, 2002: 570). Tarihi 6-8. yüzyıllara dayandırılan ve 15. yüzyılın ikinci yarısında yazıya geçirildiği tahmin edilen Dede Korkut Hikâyeleri'nde (Türk Dil Kurumu, 1995: 1031) "daz” sözcüğü "daz yir” ifadesinin içinde kullanılır: "Böyle digeç Beyrek yayı aldı çekdi, ḳabżasından yay iki para oldı. Götürdi öñine bıraḳd1, daz yirde țurgay atmağa yahşı didi”" ["Böyle diyince Beyrek yayı aldı çekti, kabzasından yay iki parça oldu. Kaldırdı önüne bıraktı, çıplak (çorak) yerde çayır kuşu vurmak için iyi dedi.”] (Ergin 1994: 143). 15. yüzyıla ait eserlerden Miftâhü'l-Lûga, Gülzâr-1 Tennûrî, Sıhahü'l-Acemî fi'lLûga; 16. yüzyıla ait eserlerden Şâmil'ül-Lûga, Et-Tuhfetü's-Seniyye, Babusü'lVâsit, Lügat-1 Ni'metu'llâh; 17. yüzyıla ait eserlerden Nuhbetü't-Tuhfe, Câmi 'ülFâris; 18-19. yüzyıllara ait eserlerden Kamus Tercümesi ve Burhân-1 Kât1 Tercümesi gibi eserlerde "daz" sözcügünün "kel” anlamıla kullanıldığı "Tarama Sözlüğü” (TS) (Türk Dil Kurumu, 1995: 1031) aracıllğıyla tanıklanabilmektedir. Berbercan (2020), 18. ya da 19. yüzyıllara tarihlenebilecek olduğunu belirterek incelediği "Kaşgar'dan Doğu Türkçesi Şiirler"in içinde, bünyesinde tekerleme- 
gülmece nitelikleri bulunduran ve "daz" biri hakkında yazılmış bir manzumeyi de incelemiş, bunu "kel yergisi" ismiyle aşağıdaki şekilde yayımlamıştır. Bu manzume, "dazlık" ve "aşağılanma-kötülenme" ilişkisini göstermesi açısından dikkat çekicidir.

diyārın kāşġar ey kac har taz / cihān bāg̀ı-da sén ḩōş mu'teber taz/ atan kimdür anay kim-dür özüy kim/ özün-nin zāatını bilmey nādān taz/ kelip yarkend yeride tuz nemek yép/ 'aḳíde ḳılmag̉an ey kūr-nemek taz/ taz çivinni ḳondurmas/ çivin taznı tındurmas/ taz dégenge tégmes/ başını kaşlap zeyikmes/ başı buḳanın başı-dék/ boyını cuvaznı̄ oḳı dék/ kéçe bolsa yatalmaydur şafak yegen kala dék/ taz çıḳtı çemen tag̉ḳa yumulandı yantaḳka/ şūm taznıj ġıçek-leri yantaḳnı çiçekleri" [Memleketin Kaşgar, ey eğri eşek kel! / Dünya bağında sen hoş (ve) muteber (bir) kel(sin) / Baban kimdir? Anan kimdir? (Sen) kendin kim(sin)?/ Kendini bilmeyen cahil kel! / Gelip Yarkend yerinde tuz nemek (nimet) yiyip/ Namaz kılmayan ey nankör kel! / Kel, sineği kondurmaz;/ Sinek, keli durdurmaz;/ Kel denen (herife) değmez,/ (Kel) başını kaşıyıp usanmaz. / Başı boğanın başı gibi,/ Boynu yayığın oku gibi,/ Gece olunca yatamaz, kabuk yiyen mal (sürü hayvanı) gibi,/ Kel çıktı çimene, dağa (tabiata); yuvarlandı kaktüse,/ Uğursuz kelin ...leri kaktüsün çiçekleri.”] (Berbercan, 2020).

19. yüzy1la ait Lehce-i Osmânî'de "daz" madde başı "sala illeti, da'ü's-saleb” biçiminde tanımlanmışken "dazlak" madde başı için "asla, büsbütün açık baş olan, akra" tanımlaması yapılmıştır (Ahmed Vefik Paşa, 2000: 111). Kamûs-1 Türkî' de (KT) ise "taz" maddesi, "baş tepesinin saçsız olması, saçın dökülmesi, sal" şeklinde ifade açıklanmıştır. Yine bu eserde "taz" sözcügüu ile ilgili olarak "da'ü'ssa'leb ile tercemesi büyük bir hatadır, zira da'ü's-sa'leb saç kıran denilen illettir, taz ise tabii bir haldir" denilmiş ve Lehce-i Osmânî’ de yapıldığ d düşünülen hata düzeltilmiştir (Şemseddin Sami, 2015: 1195). Aynı eserde "dazlak" sözcüğünün tanımlaması ise "başının tepesinde saç olmayan, başının tepesi çıplak, asla" ş̧eklindedir (Şemseddin Sami, 2015: 240). Lehce-i Osmânî ve Kamûs-1 Türkî' de "taz" sözcüğünün "kellik" ismi, "tazlak" sözcüğünün ise "kel" sıfatıyla ilişkilendirilmiş olması dikkati çeker.

\section{Tazar-}

“Kelleşmek”. “Tazardı nēn [Nesne kelleşti]” (Ercilasun ve Akkoyunlu, 2018: 254). "Taz" sözcüğünün ikincil anlamının "çıplak" biçimindedir. Bozkurt'un DLT çalışmasında da "tazar-" madde başının karşıllı̆̆ının "çıplaklaşmak, yalınlaşmak" şeklinde verildiği görülür (Bozkurt, 2016: 477). Aydemir (2017) her şeyin kelleşemeyeceğini ve bundan dolayı da bu ifadenin anlamının "nesne kötüleşti” şeklinde olması gerektiğini söyler (Aydemir, 2017: 50). Oysa nesneler 
"çıplaklaşabilì" ya da "yalınlaşabilir" [tazardı nēn. (Bir şey çıplaklaştı, yalınlaşt1.)] (Bozkurt, 2016: 477). Dolayısıyla bu fiilin anlamını DLT'de ve başka pek çok kaynakta da belirtildiği gibi "kelleşmek, çıplaklaşmak, yalınlaşmak" olarak düşünmek gerekir. "+Ar-" eki "isimlerden genellikle oluş bildiren geçişsiz-dönüşlü fiiller teşkil eden işlek bir ektir" (örn. köler-, tozar- ...) (Hacieminoğlu, 1996: 150). "Taz+ar-" yapısında da böyle bir genişleme gerçekleşmiştir.

\section{Tazgar- / Tazgir-}

"Kelleşmek /(Baş) neredeyse kel olmak". "Er başı tazgırdı. [Adamın başı neredeyse kel oldu]" (Ercilasun ve Akkoyunlu, 2018: 284). Bu sözcük başka pek çok kaynakta da DLT'deki anlamıyla verilir. Aydemir (2017) sözcüğün "kelleşmek" anlamının sıhhatinin tartışmalı olduğunu söyler ve yine DLT'de yer alan "tezgin-" [dönmek, tavaf etmek, çevrilmek] sözcügünden yola çıkarak DLT'deki cümlenin "Er başı tezgindi" [Adamın başı döndü] biçiminde olabileceğini belirtir (Aydemir, 2017: 50). Oysa DLT'de verilen 'kelleşmek, neredeyse kel olmak" anlamını esas almamak için açık bir sebep yoktur. Zira "+gAr-", "+gIr-" ekleri "oluş bildiren geçişsiz fiiller" ortaya çıkarabilen eklerdir (örn. sütger-, tozgır-vb.) (Hacieminoğlu, 1996: 152,153). "tazgar-" / "tazgır-" [kelleşmek/ neredeyse kel olmak] yapısında da buna uygun bir genişleme söz konusu olmuştur .

\section{Tazla-}

"Kel saymak, dazlak adını vermek". "Ol anı tazladı [O onu kabak (kel) saydı ve ona dazlak adını verdi]" (Ercilasun ve Akkoyunlu, 2018: 471). "Tazla-" fiili pek çok kaynakta DLT'deki anlamıyla yer alır. Eski Türklerde aşağılama için kullanılan kelimelere "+1A-" ekinin eklenmesiyle "kötüleme" anlamlı fiiller elde edilmiştir. Örneğin "ol anı 1tladı" "o ona sövüp hakaret etti ve onu köpek yerine koydu.” (Ercilasun ve Akkoyunlu, 2018: 126), "ol anı sıgırladı" “o onu sığır saydı ve onlara mensup kabul etti." Ercilasun ve Akkoyunlu (2018), "er uragutnı ekekledi" "adam kadına söverek onun kötü kadın olduğunu söyledi." (Ercilasun ve Akkoyunlu, 2018: 134). Aydemir (2014) yukarıdaki fiilleri "başkalarına kötü söylemek" anlamlı fiiller arasında siralar ancak bununla birlikte DLT'deki kimi "taz" sözcüklerinin "kötü, fena, namuzsuz" anlamlarına geldiği görüşünde olduğunu ifade eder (Aydemir, 2014: 22). Çünkü "tazla-" sözcüğünün yine DLT'de yer alan Farsça kökenli olduğu düşünülen "Tas: "Her şeyin kötüsü, bayağısı" yapısıyla bağlantılı olması gerektiğini düşünmektedir ve bu düşüncesini Türk dünya görüşüne göre kelliğin kınanılacak bir vaziyet olmadığ 1 savına dayandırır (Aydemir, 2013: 226). Oysa yukarıda "taz" sözcüğünü ele 
alırken de sıraladığımız, toplumsal bilinçaltını en açık şekilde temsil eden pek çok Türk atasözünde de görüldüğü gibi kelliğe atfedilen olumlu özelliklerin dışında Türk kültüründe kelliğin "kötüleme" ve "aşağılama" aracı olarak kullanılması son derece yaygındır. Hatta "kellik" bu türden "kötülemeler" için seçilen simgelerin başlıcalarındandır. Bu noktada "tazla-" fiilinin anlamında "taz" "çıplak, kel” ve "tas" "kötü olan her şey" sözcüklerinde varsayılan iç içe geçmişlik gerçekten söz konusu olmuşsa bile bunun kaynağının Türk toplumsal bilinçaltında yer alan "kellik"le ilgili "kötülenmeye" dair yerleşmiş ön yargılar ve bahsi geçen sözcüklerin biçimsel benzerliğinin birleşimi olmasının çok daha muhtemel göründüğünü tekraren vurgulamakta fayda vardır. Bununla beraber "1tla-", "sıgırla-", "ekekle- vb." yapılarının köklerinde de olduğu gibi toplumsal bilinçaltında "aşağılama, kötüleme" ile ilişkili olarak görülen "kel" anlamındaki "taz" sözcügünden doğrudan bu türden bir "aşağılama" fiili türetilmesi için bir engel de yoktur. "dazla-" fiilinin kullanıldı̆̆ " "Dazlayan daza düşer, kel baş̧ı kıza düşer" atasözünde toplum bilinçaltının "kellik" ile "dazla-" fiili ve "kötüleme" arasında kurduğu bağ apaçık şekilde görülmektedir. Bu atasözünde "dazla-" "güç beğenmek" anlamına gelir.

\section{Tazlak / Dazlak}

$\mathrm{Bu}$ sözcüğün tahlili ilgili çalışmalarda çoğunlukla "taz/daz+lA-k" ya da "taz/daz+1Ak" şeklinde gösterilmiştir. Karadoğan (2004) ek birleşmelerinin sebeplerini açıklarken "birden fazla yapım ekiyle türetilmiş kelimelerde birinci yapım ekli kısmın kullanımdan düşmesi" maddesi altında "dazlak" kelimesini örnek göstermiş ve buradaki birleşik ekin oluşumunu "daz+la-k>daz+lak (dazlafiili zamanla unutulduğu için)" şeklinde açıklamıştır (Biray ve Keskin, 2015: 113). "Tazla-" fiilinin aşağılama ifade etmek üzere "birini kel saymak, dazlak adını vermek" anlamına geldiği yukarıda belirtilmişti. "+1Ak" ekinin yapısındaki "+lA-" ve "-k" bireşiminden çeşitli insan tiplerini belirten aşağılayıcı anlamda sıfatlar türetildiğine göre (Korkmaz, 2007) sözcügün tabanındaki bu "aşağılama" anlamı devam ettirilerek yeni bir sıfat türetilmiş olabilir (Korkmaz, 2007: 50). Bununla birlikte, "tazla-" fiili için "kelleşmek" karşılığı da kaynaklarda gösterilmiştir (Tietze, 2002: 570; Nişanyan Sözlük, n.d.).

TS'de sözcügün ilk anlamı "saçsız, kel” (Türk Dil Kurumu, 1995: 1032) şeklinde verilir. $\mathrm{Bu}$ anlamın 15. yüzyıla ait Tuhfetü'l-Letâif'teki kullanımı aşağıdaki şekildedir: "Şol tazlak mel'unlar, Muhammed dini düşmanları kim sığır gibi yirler, ayu gibi kalkışurlar" (Türk Dil Kurumu, 1995: 1032). Yine 15. yüzyıla ait Kâbusnâme Tercümesi'nde ise şu şekilde kullanılır: "ve başınun öni dazlak ola” (Türk Dil Kurumu, 1995: 1032). Sözcüğün; 16. yüzyıl eserlerinden 
“Şâmil'ül-Lûga”, “Lügat-1 Ni'metu'llâh”, Babusü'l- Vâsıt, 18. yüzy1l eserlerinden Kanunu'l-Edeb, 19. yüzyıl eserlerinden "Kâmûs-1 Osmânî" gibi çalışmalarda da "saçsız, kel" anlamıyla kullanıldığı TS (Türk Dil Kurumu, 1995) aracılığıyla takip edilebilmektedir.

TS'de sözcügün ikincil anlamı ise "üzerinde ot bitmemiş (yer)" (Türk Dil Kurumu, 1995: 1032) şeklinde gösterilmiştir. Sözcügün; 15. yüzyıla ait "Terceman", 16. yüzyıla ait "Et-Tuhfetü's-Seniyye”ve "Kitâb-1 Bahriye" gibi çalışmalarda "üzerinde ot bitmemiş (yer)" anlamıyla kullanıldığı da yine TS (Türk Dil Kurumu, 1995: 1032) aracıllğıyla takip edilebilmektedir. Örneğin 16. yüzyıla ait Kitâb-1 Bahriye'de sözcüğün kullanımı şöyledir: "ve ol sunun kara yel tarafı bağlar bahçalardur ve şuluk dazlakdur" (Tietze, 2002: 570).

\section{“TAZ/DAZ” VE “TAZLAK/DAZLAK” SÖZCÜKLERININN ÖLÇÜNLÜ TÜRKIYY TÜRKÇESİ, TÜRKIYE TÜRKÇESİ AĞIZLARI VE ÇAĞDAŞ TÜRK LEHÇELERINDEKİ DURUMU}

TDK Güncel Türkçe Sözlük’te (GTS) (Türk Dil Kurumu, n.d.) "daz” "1. sıfat, halk ağzında Dazlak; 2. sıfat, halk ağzında Çıplak (toprak)" şeklinde; "dazlak" ise "sıfat Başında saçı olmayan (kimse, baş), daz" şeklinde kayıtlıdır. Görüldüğü üzere ölçünlü Türkiye Türkçesinde bu sözcükler birbirleriyle eş anlamlı olarak kullanılmaktadır. Ölçünlü Türkçedeki kimi kullanımlarda "daz” için “doğuştan ya da tabii sebeplerden dolayı kel"; "dazlak" içinse "sonradan kel haline getirilmiş, dazlaştırılmış kel" ayrımı sezilse de hem ölçünlü Türkçede hem de Türkçenin tarihî dönemlerinde böyle bir ayrıma gidilmeksizin "taz/daz" ile "tazlak/dazlak" sözcükleri birbirlerinin yerine de kullanılabilmiştir.

Nişanyan Sözlük’te de (NS) belirtildiği gibi ölçünlü Türkiye Türkçesinde "dazlak" sözcügü yeni bir anlam daha kazanmıştır: “(Almanya'da) Neo-nazi serseri" (Nişanyan Sözlük, n.d.). Bu kullanım daha geniş anlamda "Saçını isyan, 1rkçılık veya anarşinin sembolü olarak kazıtan ve genellikle şiddet yanlısı bir grup ya da çete mensubu olan antisosyal kişi” olarak tanımlanabilir. Türkçeye, yabancı dil kaynaklı olarak giren bu kullanımı karşılamak için "kel", "daz" vb. sözcüklerin değil de "dazlak" sözcügünün tercih edilmiş olması akla tekrar "saçın sonradan kel hale getirilmesi"ni ve "dazlak" isminin kendisinden türediği "tazla" fiiline yüklenen "kelleşmek" anlamını getirmektedir. Bununla birlikte "+lAk" ekinin yapısındaki "+1A-" ve "-k" bireşiminden çeşitli insan tiplerini belirten aşağılayıcı anlamda sıfatlar türetilmesi de bu kullanımın tercih edilmesine etkide bulunmuş olmalıdır. Zira toplum, diğerlerinin haklarını umursamayan, antisosyal birey ya da gruplara karşı olumsuz bir bakış açısına sahiptir ve bu türden "kınama, aşağılama, küçümseme" anlamlı yapılarla söz konusu bakış açısı ifade edilmiş 
olur. “Taz/daz” ile "tazlak/dazlak” sözcükleri her ne kadar birbirlerinin yerine kullanılabilse de böyle sezdiriler, bahsi geçen sözcüklerdeki anlamsal döngü aşamalarının henüz nihayete ermediğini bir kez daha göstermektedir. Mezkûr sözcükler birbirlerinin yerine kullanılabildiğine göre anlamsal döngü süreci başlamıştır ancak genç sözcük "dazlak", tabanı "daz" sözcüğünü henüz kullanımdan tamamen düşürmediğine göre zayıflamış da olsa hala bir anlamsal fark taşıyor olmalıdır.

“Taz” sözcüğü “Türkiye'de Halk Ağzından Derleme Sözlügü̈”nde (DS) (Türk Dil Kurumu, n.d.) "Çıplak, saçsız baş” [*Bornova -İzmir] tanımlamasıyla yer alır ve [-> tazlak] şeklinde bir de yönlendirme içerir. "Tazlak" sözcüğü de aynı şekilde "Çıplak, saçsız baş" [ Bornova -İzmir $]$ tanımlamasıyla kendine yer bulur. Sözcüğün "daz" biçiminin ise DS'de (Türk Dil Kurumu, n.d.) farklı pek çok tanımlaması vardır. Bunların tümünün "kellik" ya da "çıplaklık”la bağlantılı olduğu görülür. Bu tanımlamalar şöyledir:

"Kellerin başında kellikten geri ye kalmış izlere denir: Çoğu gitti azı kaldı, keli gitti dazı kaldı." [Elbistan -Maraş; Yendiğin *Ilgın -Konya]; "Saçsız baş, kel.” [*Edremit -Balıkesir; *Düzce -Bolu; -Sinop ve çevresi; -Amasya; *Zile Tokat; Bayburt, İrişli *Sarıkamış, *Iğdır -Kars; -Van; *Kilis -Gaziantep; *Divriği -Sivas; *Ayaş -Ankara; *Pınarbaşı -Kayseri; *Bor -Niğde; -Adana; *Karaağaç Tekirdağ]; "Otsuz, çıplak arazi, tepe" [Çelik *Besni -Malatya; Önsen, Bertiz Maraş;*Akdağmadeni -Yozgat; Başlamış *Dörtyol -Hatay; *Osmaniye -Adana]; "Kadının cinsiyet organı" [Ortaköy *Şarkışla -Sivas; -Yozgat; Köşker -Kırşehir; Civanyaylağ1 -İçel]; "Kel çıplak" [Elazı̆̆ ve Yöresi]; "Kel” [Erzurum].

"Dazla-" fiili farklı anlamlarla DS'de (Türk Dil Kurumu, n.d.) mevcuttur. Bunlardan "ayıplamak, kınamak" anlamlı olan yapı, "başkalarına kötü söyleme" niteliği taşıyan "Kel saymak, dazlak adını vermek" doğrudan bağlantılı olmalıdır. "Dağlamak" anlamlı "dazlamak" sözcüğü için Güvenen (2017) “-ğ->-z-", "dağlamak>dazlamak" değişiminin söz konusu olduğunu söylemiştir (Güvenen, 2017: 140). "Kizartmak" anlamında da "dağlamak" bağlantısı sezilmektedir. "Kaçmak" anlamlı "dazlamak" ise aynı sözlükte yine aynı anlamla yer alan "dazmak" yapısıyla ilişkilidir. DS'deki (Türk Dil Kurumu, n.d.) anlamlar şu şekilde sıralanabilir:

“Ayıplamak, kınamak" [Bayat *Emirdağ -Afyon; *Alaşehir -Manisa; *Üsküdar -İstanbul; -Kastomonu; *Gürün -Sivas; -Kayseri; *Bor -Niğde]; "Dağlamak: Sı̆̆ırın ayağına mıh batmış, çıkarıp dazlatmalı." [Aliköy *Çaycuma

"Yahut “tas+lA-" "Kötülüğe nispet etmek” (Aydemir, 2017: 51). 
-Zonguldak]; Kızartmak, kebap yapmak [Karabüzey -Kastamonu Küçükisa; *Zile -Tokat]; Kaçmak [*Ulubey -Ordu] (Türk Dil Kurumu, n.d.).

"Dazlak" sözcügü için DS'de (Türk Dil Kurumu, n.d.) "[-> daz(I) -3]” yönlendirmesi ile beraber muhtelif anlamlar söz konusudur. Sözcüğün ağızlarda da çıplak arazi ve tepeleri tasvir etmek için kullanılması dikkat çekmektedir. "+1Ak" eki hayvan adları yapımında ve özellikle kuş adları yapımında kullanılır (Tietze, 2002: 22). Anadolu ağızlarında da bu ekin kullanıldığı kuş adları mevcuttur (Örn. baatlah, bartlak, boğartlak, boğurtlak, kamalak vb.) (Mutlu, 2013: 52). Leylek anlamlı "dazlak" sözcüğü de bunlardan biridir. Kendisine atfedilen olumlu özelliklerin dışında Türk kültüründe kelliğin "kötüleme" ve "aşağılama" aracı olarak da sıklıkla kullanıldığ 1 yukarıda örneklerle belirtilmişti. Bu kötülemelerden bir kısmı "kellik" ve "utanmazlık" ilişkisi üzerinedir. DLT'de yer alan "Çakşak üze ot bolmas, çakrak bile uwut bolmas" "Dağın taşlık yerinde ot yoktur, kel adamda ise haya yoktur" (Ercilasun ve Akkoyunlu, 2018: 205) atasözü bu ilişkiyi açıkça göstermektedir. "Kaba adam, terbiyesiz" anlamlı "dazlak" sözcügüü bu anlayıştan yola çıkılarak oluşturulmuş olmalıdır. Yine "ayı" anlamlı dazlak sözcüğü de kabalık bağlamıyla alakalı bir örtmece sözcük olabilir 6 .

"Otsuz, çıplak arazi, tepe" [Körküler *Yalvaç -Isparta; Yayla *Tefenni Burdur; *Akyazı çevresi -Kocaeli; -Giresun; Aşudu *Darende -Malatya; Hamurcu *İncesu -Kayseri; Bayafşar, Elmasun *Çumra, Botsa -Konya; Isırganlı -Adana; Gezende -İçel]; Ay1 [-Kütahya; -Balıkesir]; Leylek [Bursa]; Ham meyve [Kayseri]; Bir kısmı hafifçe yanmış şey [Çepni *Gemerek -Sivas]; Kaba adam, terbiyesiz: Bir türlü yola geleceği yok, dazlak adamın biri [ ${ }^{*}$ Çarşamba köyleri Samsun; *Nizip -Gaziantep] (Türk Dil Kurumu, n.d.).

\footnotetext{
${ }^{5} \mathrm{Bu}$ atasözündeki "çakrak" sözcüğünün aktarımı ile ilgili muhtelif görüşler vardır. Bu atasözünün "dağ çakşağında ot olmaz, çıplakta utanma olmaz" ve "dağ çakşağında ot olmaz yanşak kişide ar olmaz" vb. aktarımları mevcuttur. Aydemir (2012: 28; 2017: 51) önceleri “dağ çaksağında ot, başı açıkta haya olmaz” şeklinde açıkladığı bu atasözünü daha sonra yaptığı çalışmalarında "dağ çakşağında ot, mutribe, muganni ve rakkasta uwut/ utanma olmaz” şeklinde aktarmıştır. Aydemir'e göre kellikle utanmazlığın bağdaştırılması Türk düşünce dünyasıyla uyuşmaz. Aynı bakış açısı doğrultusunda "tazla-" fiilini de "taz" "kel, çıplak" kelimesi yerine "tas" "bir şeyin en kötüsü" sözcüğüyle ilişkilendirdirdiğinden de yukarıda bahsedilmişti.

6 “Ayı" sözcüğü ile "kabalık” arasındaki ilişki ölçünlü Türkçede de mevcuttur. GTS'de (Türk Dil Kurumu, n.d.) "ayı” sözcüğünün ikincil anlamı "kaba saba olan insanlar için kullanılan bir seslenme sözü” biçimindedir.
} 
"Dazlak" sözcüğünün çağdaş Türk lehçelerindeki karş1l1kları şu biçimdedir: Azerbaycan Türkçesinde "daz"; Başkurt Türkçesinde yaltas, kak baş(l1), yaltır baş(11); Kazak Türkçesinde "taz", "jaltır bas"; Kırgız Türkçesinde "taz", "kal”; Özbek Türkçesinde "käl”, "tàz"; Tatar Türkçesinde "piläş", "takır başlı", "yaltır başl1"; Türkmen Türkçesinde; "kel”, "takır kelle" ve Uygur Türkçesinde "taz", "aydinvaş", "kaşkıvaş" (Ercilasun, 1991: 153).

“Taz/daz” sözcügünün türevleri de çağdaş Türk lehçelerinde çeşitli şekillerde kendilerine yer bulmuştur. Örneğin: Altay Türkçesinde "taza-" "kel olmak"; "tazada” ("tazat-” fiilinden zarf-fiil) "çaçın tazada kayçı saldı" "saçını kökünden kazıdı"; "tazat-" "kelleştirmek (Gürsoy Naskali ve Duranl1, 1999: 171). Azerbaycan Türkçesinde "daz" "daz"; "dazay": "1.tahsilsiz, öğrenimsiz. 2.Görgüsüz, kaba"; "dazbaş" "dazlak"; "dazlanma" "1.kelleşme 2.kıraçlaşma 3.Yaprakları dökülme"; "dazlanmag" "kelleşmek"; "dazlaşdırmag” "1.kelleştirmek 2.kıraçlaştırmak 3.çıplaklaştırmak"; "dazlaşma" "1.kelleşme 2.kıraçlaşma 3.Yaprakları dökülme"; "dazlaşmag" "1.kelleşmek 2.kıraçlaşmak 3.çıplaklaşmak"; "dazlaşmış" "dazlak, kel” (Akdoğan, 1999: 180). Hakas Türkçesinde "tazar-" "kelleşmek"; "tazart-" "kelleştirmek"; "tazarta" "dazlak şekilde, kel gibi"; "tazay-" "ayakları açık vaziyette ayakta durmak" (Arıkoğlu, 2005: 487). Tuva Türkçesinde "das" "akbaba"; "tas" 1."kel, dazlak" 2. "çıplak, ağaçsız" 3. çok güzel, mükemmel”; "tastaar" "tüyleri dökülmek"; "tazarar" "kelleşmek" (Arıkoğlu ve Kuular, 2003: 106). Saha Türkçesinde "tarağay" “dazlak” (Vasiliev, 1995: 61). Yeni Uygur Türkçesinde "taz” "1.kel 2.Uyuz"; “tazkara” "anka”, “korultaz” "anka” (Necipoviç, 1995: 244, 395, 396).

\section{“TAZ/DAZ”, "TAZLAK/DAZLAK", “+lAk" EKİ VE ANLAMSAL DÖNGÜLER}

İsimden fiil yapan "+1A-" ekiyle fiilden sıfat yapan "-k" ekinin içe içe geçmesinden müteşekkil bir birleşik ek olan +lAk eki, kaynaşmaya uğramasının ardından özel bir nitelik kazanarak insan tiplerini belirten aşağılayıcı anlamda sıfatlar ortaya çıkarmıştır (Korkmaz, 2007: 50). NS'de (Nişanyan Sözlük, n.d.) birkaç örnekte kusur sıfatları kuran bu ekin yoksunluk bildiren sıfatlar türeten müstakil bir ek olma eğilimi gösterdiği belirtilir. Banguoğlu (1990) da ekin insan tipleri belirten aşağılama anlatımıla sıfatlar yapma niteliğini vurgular (Banguoğlu, 1990: 187). Bu ekin, toplumun yaşam tarzına aykırı hareketleri yahut fiziksel kusurları belirten sıfatların üzerine geldiğinde fonksiyon değiştirebildiğine dair görüşler de vardır (Çelik, 2020: 90). H. İbrahim Delice (2000) genişletme ekleri hakkında "işlevi sözlükbirimlerin çeşitli kavramlarla ilgi kurmasını sağlayarak onları genişletmektir; ki bu, onların ne kavram alanı ne 
görevini değiş̧tirir ne de başka bir sözlükbirimle bağlantı kurmasını sağlar" şeklinde bir açıklama yapmıştır. Bu ekler; yeni sözcükler türetmedikleri, onları kapsamı kendileriyle sınırlı kalan ${ }^{7}$ (Gülsevin, 2004: 1280) çeşitli anlam ilaveleriyle genişlettikleri için (Delice, 2012: 92) işlev kaybına uğramaya, türetme eklerine oranla daha fazla eğilimlidir. Dolayısıyla anlamsal döngülere de daha fazla sebebiyet verir (Çelik, 2020: 44).

Çalışmanın "giriş" kısmında "taz / daz $\Leftrightarrow$ dazlak" eklemlenmesinde anlamsal döngü sürecinin başlamış olduğundan ancak henüz nihayete ermediğinden söz edilmişti. "Türkiye Türkçesinde Anlamsal Döngü ve Döngülü Sözcük Örnekleri”" (Çelik, 2020) isimli çalışmada "yoksunluk, aşağılama, küçük görme vb. bildiren sifatlar türetme işlevi bulunan '+1Ak' ekinin leksik olarak "yoksunluk bildirme vb." kavram dairesini çağrıștıran anlamları bünyesinde taşıyan sıfat tabanlarına eklendiğinde, bu sözcükleri aşağılama, küçük görme vb. anlamlarıyla genişlettiği, yani bir genişletme eki görevi gördüğü, dolayısıyla da ekin bu işlevli kullanımlarının, türetme eki olarak değil, genişletme eki olarak kabul edilmesi gerektiği” düşüncesi savunulmuştur.

Şu da belirtilmelidir ki +1A-k eki 'dişlek, götlek, ödlek vb.' yapılarda tarz olarak aşağılama belirtirken aynı zamanda bu yapıların kök anlamlarından farklı anlama gelen sıfatlar da türetmiş yani türetme eki olarak görev almıştır (örn. diş: çene kemiklerinin üstüne dizili, 1sırıp koparmaya ve çiğnemeye yarayan sert, beyaz organlardan her biri; dişlek: dişleri dışarıya doğru çıkık olan kimse) (Nişanyan Sözlük, n.d.). Ancak 'aylak' ve 'dazlak' gibi örneklerin kimi kullanımlarında +lA-k eki yalnızca 'aşağılama' ifade eder, farklı bir sözcük türetmez (örn. daz=dazlak; dazlak=daz) (Nişanyan Sözlük, n.d.) (Çelik, 2020).

Sosyal psikoloji, toplumsal hayat tarzına mugayir davranışları ya da fiziksel kusurları kötülemeyi, aşağılamayı veya küçümsemeyi normalleştirebilmektedir. Bunun sonucunda söz konusu bakış açısını yansıtan kullanımlar sıradanlaşır. Leksik olarak 'yoksunluk bildirme, toplum hayat tarzına aykırı davranış ifade etme vb.' anlam yapısını bünyesinde barındıran tabanlara 'yoksunluk, aşağılama, küçük görme vb. bildiren sıfatlar meydana getirme işlevi bulunan" +lAk eki, bu bakış açısını öne çıkarmak ve vurgulamak adına getirildiğinde, zamanla ekin bahsi geçen fonksiyonu bu sıradanlaşma dolayısıyla silikleşir ve ardından tamamen yitebilir. "Taz / daz $\Leftrightarrow$ tazlak/ dazlak" gelişiminde silik de olsa söz

${ }^{7}$ Gülsevin (2004: 1280) 'kategori ekleri' adını verdiği ulamı açıklarken bu ifadeyi tercih etmiştir. 
konusu farklılık zaman zaman kendini belli eder. Aynı genişlemenin "*ay $\Leftrightarrow$ aylak" sözcükleri için de söz konusu olması muhtemeldir.

"Aylak" sözcügüyle ilgili olarak ${ }^{8}$ en çok benimsenen görüş onun "ayla-" fiilinden türediğidir. "Ayla-" fiilinin $<* \bar{a} y$ isminden türediğini söyleyen görüssle birlikte bu fiilin $<* \bar{a} y$ - fiil kökünden nötr işlevli -lA- fiilden fiil ekiyle türetildiği yönünde görüssler de mevcuttur (Kaman, 2020: 169). Bu noktada fiilin kökeninin, kullanımı oldukça kısıtlı olan ve hatta birtakım kullanımları "-AlA-" ekiyle karıştırılan (Banguoğlu, 1990: 278; Korkmaz, 2007: 125,126; Hacıeminoğlu, 1991: 113) nötr işlevli "-lA-" ekiyle ve dolayısıyla da bir fiil tabanıyla ilişkili olması görüşündense Türkçenin en sık kullanılan eklerinden biri olan isimden fiil yapan "+1A" eki ile, dolayısıyla da bir isim tabanıyla ilişkili olması görüşünün doğruluğunun çok daha muhtemel olduğu görülmektedir. "Ayla-” fiilinin isimden türediğini söyleyen görüşler, ayın kendi etrafında dönmesiyle ilgili bir ilişki kurarak bu görüşlerini temellendirirler. Bunun yanında, bu fiilin yapısıyla ilgili olarak Gülensoy'un (2007: 407) "haylaz" sözcüğünün kökenini açılarken gösterdiği *<ay "boşta gezen" *ay+la- "boşta gezmek, dolaşmak" çözümlemesi dikkate değerdir. Söz konusu çözümleme doğrultusunda düşünüldüğünde bu yapılarla ilgili olarak da tıpk1 "taz / daz $\Leftrightarrow$ tazlak / dazlak" yapılarındakine benzer bir anlamsal döngüden bahsetmek mümkündür (Çelik, 2020: 91).

Bu noktada, hem "taz / daz $\Leftrightarrow$ tazlak/ dazlak" hem de "*ay $\Leftrightarrow$ aylak" örneklerinde bir anlamsal döngü sürecinin söz konusu olmasında "+1Ak" ekinin, kimi kullanımlarda "türetme eki" olarak değil de "genişletme eki" olarak işlev görebilmesinin temel etken olduğu çıkarımı üzerine düşünülmelidir.

\section{SONUÇ}

Türkiye Türkçesinde her ikisi de "başında saçı olmayan (kimse, baş)" (Türk Dil Kurumu, n.d.) anlamlarıla kullanılan "daz" ve "dazlak" sözcüklerinin kökeninin Ana Altaycadaki varsayımsal " $t$ "éro" yapısına dayandı̆̆ 1 belirtilmektedir. Türkçenin etimoloji sözlüklerinde "taz/daz" ve "tazlak/dazlak" sözcükleriyle ilgili olarak çoğunlukla benzer bilgiler tekrarlanır ve "tazlak/dazlak" sözcüğü genellikle "taz/daz+lA-k" ya da "taz/daz+lAk" şeklinde tahlil edilir.

8 “Aylak” sözcüğü hakkında ayrıntılı bilgi için bk. Kaman, S. (2020). Aylak sözcüğü üzerine. Dil ve Edebiyat Araştırmalarl, 21, 149-174. https://doi.org/10.30767/diledeara.673285 
DLT'de "taz" sözcüğü, "saçsız, kel” anlamlarının yanı sıra genişletilmiş biçimleriyle başka kullanımlarla da yer alır. Bu kullanımlar "taz kōy", "taz yir" ve "taz at" biçimindedir. Bahsi geçen yapılarla ilgili DLT'de verilen anlamların dışında farklı anlamlandırma görüşleri söz konusu ise de "taz kōy" için verilen "boynuzsuz koyun" ve "taz yir" için verilen "çorak, bitkisi az olan yer" karşılıkları Türk dilindeki başka kullanımlar aracılığıyla büyük oranda doğrulanabilmektedir. Fakat "taz at" ifadesinin DLT'de belirtilen "at donu" bildirme anlamı şüphelidir. Bu konuda muhtelif görüşler mevcut olmakla beraber bu görüşler arasında "nalsız at, ayağı çıplak at" görüşü bilhassa dikkat çekicidir. "Taz" sözcügünün türevlerinden "tazar-”, "tazgar-/tazgır-”, "tazla-/dazla-" ve "tazlak/dazlak" gibi sözcükler hakkında da yine fikir birliği mevcut değildir. DLT'de karşı1lı̆̆ "kelleşmek" olarak gösterilen "tazar-", "taz” kelimesinin yan anlamıyla bağlantılı "yalınlaşmak, çıplaklaşmak" olarak da algılanabilir. Yine DLT'de anlamı "kelleşmek / (baş) neredeyse kel olmak" olarak gösterilen, yapı ve anlamı hakkında kimi farklı ifadeler ortaya konan "tazgar-" / "tazgır-" fiillerinin DLT'deki anlamını esas almamak için açı bir sebep yoktur. Zira "+gAr-", "+gIr-" ekleri "oluş bildiren geçişsiz fiiller" ortaya çıkarabilen eklerdir "tazgar-" / "tazgır-" yapısında da buna uygun bir genişleme söz konusu olmuştur. Bazı çalışmalarda, DLT'deki anlamı "kel saymak, dazlak adını vermek" şeklinde gösterilen "tazla-" fiilinin kötüleme amaçlı kullanımı göz önüne alınmış ve Türk kültüründe "kellik"e yüklenen olumlu ve kutsî özellikler değerlendirilerek bu sözcüğün anlamının "kellik" ile ilgili olamayacağını söyleyen savlar üretilmiştir. Oysa toplum bir kavram üzerinden çok farklı bakış açılarını ifade edebilmektedir ve kelliğe atfedilen olumlu özelliklerin dışında Türk kültüründe kelliğin "kötüleme" ve "aşağılama" aracı olarak kullanılması son derece yaygındır. Hatta "kellik" bu türden "kötülemeler" için seçilen simgelerin başlıcalarındandır. Dolayısıyla benzer diğer yapılarda da görüldüğü gibi "taz" sözcügünden doğrudan bir "aşağılama" fiili türetilmesi için bir engel yoktur.

Çalışmalarda "tazla-" fiilinin "kelleşmek" karşılığından da bahsedilmiştir. "Tazlak/Dazlak" sözcüğünün Türk dilinin tarihî kaynaklarındaki kullanımlarına bakıldığında bu sözcüğün "saçsız, kel" ve "üzerinde ot bitmemiş (yer)" anlamlarında kullanıldığı fark edilir. "Daz" sözcüğünün ölçünlü Türkiye Türkçesindeki karşlıkları da yine "dazlak" ve "çıplak toprak" olarak karşımıza çıkar. "Dazlak" sözcügünün karşıllı̆ı olarak da "başında saçı olmayan (kimse, baş), daz" tanımlaması görülür.

Bazı kullanımlarda "daz" ve "dazlak" sözcükleri arasında "doğuştan kel olma" ve "sonradan kelleşme" üzerinden küçük anlam farklılıkları sezdirilse de hem ölçünlü Türkçede hem de Türkçenin tarihî dönemlerinde böyle bir ayrıma 
gidilmeksizin "taz/daz" ile "tazlak/dazlak" sözcükleri birbirlerinin yerine de kullanılabilmiştir. Türkiye Türkçesinde "dazlak" sözcügü yeni bir anlam daha kazanmıştır. Bu anlam geniş anlamıyla "Saçını isyan, 1rkçılık veya anarşinin sembolü olarak kazıtan ve genellikle şiddet yanlısı bir grup ya da çete mensubu olan antisosyal kişi" olarak tanımlanabilir. Yabancı dil kaynaklı bir kavram olarak dile giren bu terimi karşılamak için "daz" veya "kel" değil de "dazlak" sözcügünün tercih edilmiş olması "tazla-" fiili kaynaklı "sonradan kelleşme" anlamı ve "+1Ak" ekinin yapısındaki "aşağılama" anlatımı katma niteliğiyle alakalı olmalıdır.

"Daz" sözcüğü ve türevlerinin Anadolu ağızlarındaki kullanımlarına bakıldığında çoğunlukla "kellik" ya da "çıplaklık"la bağlantılı anlamlarla karşılaşıllır. Bununla beraber başka yan anlamlara yönelik türetimler de söz konusu olmuştur. Sözcüğün çağdaş Türk lehçelerindeki gelişimine bakıldığında (Çağdaş Türk lehçelerindeki karş1lıklar için bk. Ercilasun, 1991: 152,153) diğer pek çok lehçede "taz/daz yapısının /+1Ak/ eki almamış biçimlerinin yaygın olduğu görülmektedir (Çelik, 2020: 93).

Hem “taz/daz $\Leftrightarrow$ tazlak/ dazlak" hem de “*ay $\Leftrightarrow$ aylak” örnekleri incelendiğinde bu yapılarda söz konusu olan anlamsal döngü süreçlerinin "+lAk" ekinin işleviyle ilgili olduğu, bahsi geçen ekin bu örneklerde "türetme" fonksiyonuyla değil de yalnızca "aşağılama" bildiren bir "genişletme eki" fonksiyonuyla görev aldığı için tespit edilen anlamsal döngülerin ortaya çıkmış olabileceği üzerine düşünülmeli ve genel olarak Türkçedeki eklerin "genişletme" işlevleri üzerine tartışılmalıdır.

\section{KISALTMALAR}

DLT: Dîvânu Lugâti’t-Türk

DS: Türkiye'de Halk Ağzından Derleme Sözlüğü

EDPT: An Etymological Dictionary of Pre-Thirteenth Century Turkish

ET: Eski Türkçe

GTS: Türk Dil Kurumu Güncel Türkçe Sözlük

NS: Nişanyan Sözlük Çağdaş Türkçenin Etimolojisi

TDK: Türk Dil Kurumu 
TS: Tarama Sözlüğü

\section{KAYNAKLAR}

Ahmed Vefik Paşa (2000). Lehçe-i Osmânî (R. Toparlı, Ed.). Türk Dil Kurumu Yayınları.

Arıkoğlu, E. (2005). Örnekli Hakasça-Türkçe sözlük. Akçağ Yayınları.

Arıkoğlu, E. ve Kuular, K. (2003). Tuva Türkçesi sözlüğü. Türk Dil Kurumu Yayınları.

Atlı, S. (2019). Dîvânu Lugâti't-Türk’teki atasözleri üzerine yapılan bir çalışma: Abdülahad Nûrî ve atalar sözü. Manas Sosyal Araştırmalar Dergisi, 8(3), 2243- 2279. https://doi.org/10.33206/mjss.528134

Aydemir, A. (2012). Divanü Lugati’t Türk’te aşk ve cinsellik üzerine. The Journal Of Academic Social Science Studies, 5(2), 15-41. https://doi.org/10.9761/jasss_45

Aydemir, A. (2012). Kutadgu Bilig ve Divanü Lugati’t Türk’e göre saç-sakal kültürü üzerine. Turkish Studies -International Periodical For The Languages, Literature And History Of Turkish Or Turkic, 7(3), 329-350. http://dx.doi.org/10.7827/TurkishStudies.3421

Aydemir, A. (2014). Divanü Lûgat-it-Türk'e göre insanlar arasındaki ilişkilerde nezaket. Teke Uluslararası Türkçe Edebiyat Kültür Ĕ̈itim Dergisi, 3 (3), 14-36. https://doi.org/10.7884/teke.344

Aydemir, A. (2013). Divanü Lugati’t Türk’te problemli iki cümle üzerine. Turkish Studies -International Periodical For The Languages, Literature And History Of Turkish Or Turkic-, 8 (4), 223-231. http://dx.doi.org/10.7827/TurkishStudies.3483

Aydemir, A. (2017). Divanü Lûgati't-Türk'te 'kötü' anlamındaki sözcükler üzerine. Route Educational And Social Science Journal, 4 (2), 43-56. https://doi.org/10.17121/ressjournal.577

Banguoğlu, T. (1990). Türkçenin grameri, Türk Dil Kurumu Yayınları. 
Berbercan, M. T. (2020). Kaşgar'dan Doğu Türkçesi şiirler [çeviriyazı - aktarma söz varlığı - tıpkıbasım]. Türk Dünyası Dil ve Edebiyat Dergisi, 49, 137159. https://doi.org/10.24155/tdk.2020.132

Beydilli, C. (2005). Türk mitolojisi ansiklopedik sözlük. Yurt Kitap Yayınları.

Biray N. and Keskin E. G. (2015). Birleşik eklerle ilgili bir teori denemesi. Türk Kültürü, 2015/2, 109-134.

Bolat, N. (2017). Keloğlan kimliğinde türk masalları anlatısı: Propp yönteminde Türk masalları. Manas Sosyal Araştırmalar Dergisi, 6 (3), 201-226.

Bozkurt, F. (2016). Kaşgarlı Mahmud Divân-ü Lugat-it-Türk. Salon Yayınları.

Clauson, S. G. (1972). An etymological dictionary of pre-thirteenth century Turkish. Oxford University Press.

Çelik, A. (2016, April 28-30). Türkiye Türkçesi atasözü ve deyimlerinde toplumun delilik algisı. Bartın Üniversitesi Edebiyat ve Toplum Sempozyumu, Bartın, Türkiye. https://bit.ly/3ea7WuJ

Çelik, A. (2020). Türkiye Türkçesinde anlamsal döngü ve döngülü sözcük örnekleri. Hiper Yayın.

Delice, H. İ. (2000). Türk dilinde işlevsel ek tasnifi denemesi. Türklük Bilimi Araştırmaları, 9, 135-149.

Delice, H. İ. (2012). Sözcük türleri. Asitan Yayınevi.

Eckmann, J. (2014). Nehcü'l-ferâdîs cennetlerin açık yolu-Mahmūd Bin Alî (S. Tezcan, H. Zülfikar and A. Ata Eds.). Türk Dil Kurumu Yayınları.

Efe, K. (2018). Eski Türkçe döneminde hayvan türlerinin adlandırılması. International Journal Of Languages' Education and Teaching, 6(4), 329352. https://doi.org/10.18298/ijlet.3215

Ercilasun, A. B. (1991). Karşılaştırmalı Türk lehçeleri sözlüğü I-II. Kültür Bakanlığı Yayınları.

Ercilasun, A. B. ve Akkoyunlu Z. (2018). Kâşgarlı Mahmut Dîvânu Lugâti't-Türk giriş metin-çeviri notlar-dizin. Türk Dil Kurumu Yayınları.

Eren, H. (1986). Türk dilinin etimolojik sözlüğü. Bizim Büro Basımevi. 
Ergin, M. (1994). Dede Korkut kitabı I. Türk Dil Kurumu Yayınları.

Ergun, P. (2005). Altay destanlarında ve Anadolu Türk masallarında TastarakayKeloğlan. Millî Folklor Dergisi, 68, 78-84.

Eyuboğlu, İ. Z. (1991). Türk dilinin etimoloji sözlüğü. Sosyal Yayınlar.

Giese, F. (1929). Die Altosmanische chronik des Aşıkpaşazāde. Harrassowitz.

Gülensoy, T. (2007). Türkiye Türkçesindeki Türkçe sözcüklerin köken bilgisi sözlüğ̈̈ I-II. Türk Dil Kurumu Yayınları.

Gülsevin, G. (2004, September 20-26). Türkçede sıra dışı ekler ve eklerin tasnif tanımlama sorunu üzerine. V. Uluslararası Türk Dili Kurultayı, Ankara, Türkiye. https://bit.ly/3turNvd

Güvenen, E. (2017). Derleme Sözlüğü’nde görülen $/ \breve{g} /$ eksenli ses olayları. Akademik Hassasiyetler, 4 (7), 147-165.

Hacıeminoğlu, N. (1991). Türk dilinde yapı bakımından fiiller. Kültür Bakanlığı Yayınları.

Hacıeminoğlu, N. (1996). Karahanlı Türkçesi grameri. Türk Dil Kurumu Yayınları.

Kaman, S. (2020). Aylak sözcüğü üzerine. Dil ve Edebiyat Araştırmaları, 21, 149174. https://doi.org/10.30767/diledeara.673285

Karadoğan, A. (2004). Türkiye Türkçesinde birleşik eklerle oluşturulmuş sözlük ögeleri. Türk Dili, 2004/634, 541-549.

Korkmaz, Z. (2007). Türkiye Türkçesi grameri (şekil bilgisi). Türk Dil Kurumu Yayınları.

Mutlu, E. (2013). Derleme Sözlüğü'nde kuş adları [Unpublished master's thesis]. Yozgat Bozok Üniversitesi.

Nişanyan, S. (n.d.). Nişanyan sözlük. https://www.nisanyansozluk.com/

Ögel, B. (1991). Türk kültür tarihine giriş. Kültür Bakanlığı Yayınevi.

Ögel, B. (2002). Türk mitolojisi, cilt II. TTK Yayınları. 
Sağol, G. (1994, May 11-14). Tarihi şivelerde at donları [Paper presentation]. Türk Kültüründen At ve Çağdaş Atçılık Sempozyumu, İstanbul, Türkiye. https://bit.ly/3glX5ke

Şemseddin Sami (2015). Kamus-ı Türkî (P. Yavuzarslan, Ed.). Türk Dil Kurumu Yayınları.

Şimşek, E. (2017). Türk masallarının millî tipi: Keloğlan. Akra Kültür Sanat ve Edebiyat Dergisi, 11, 41-57. https://doi.org/10.31126/akrajournal.328047

Starostin, S., Dybo, A. and Mudrak, O. (2003). An etymological dictionary of the Altaic languages (3 vols). Brill.

Tergip, A. (2014). Türk atasözleri ve deyimlerinde kötüleme ifadeleri. Folklor/Edebiyat, 20 (80), 275- 294.

Tietze, A. (2002). Tarihî ve etimolojik Türkiye Türkçesi lugati. Simurg Yayınları.

Türk Dil Kurumu (1995). Tarama sözlüğü. Türk Dil Kurumu Yayınları.

Türk Dil Kurumu (n.d.). Türk Dil Kurumu sözlükleri. https://sozluk.gov.tr/

Vasiliev, Y. (1995). Türkçe-Sahaca sözlük, Türk Dil Kurumu Yayınları. 